\title{
Tiroid Kanserleri: Tanı ve Cerrahi Tedavisi
}

\author{
Thyroid Cancers: Diagnosis and Surgical Management
}

\author{
Abdülhak Hamit KARAYAĞIZ ${ }^{1}$, Ekrem FERLENGEZ ${ }^{2}$ \\ 1. Acıbadem Üniversitesi International Acıbadem Hastanesi Transplant Merkezi, Istanbul, Türkiye \\ 2. Sağlık Bilimleri Üniversitesi Haseki Ĕ̆itim Araştırma Hastanesi Genel Cerrahi Kliniği, İstanbul, Türkiye
}

\section{$\ddot{O Z E T}$}

Amaç: Tiroid kanserleri çok defa karşımıza soliter hipoaktif bir nodül olarak çımakta ancak bu nodülün malignite tanısı koyulmasındaki bir takım güçlükler uygulanan cerrahi girişim seçimini de zorlaştırmaktadır. Tiroid kanseri tanisı ile opere edilen hastalarda tiroid kanser tanisl ve tedavisinin uygulanmast için gerekli cerrahi yöntem tercihini belirlemek amacıyla bu çalışmaya yöneldik.

Gereçler ve Yöntem: Haseki Ĕ̆itim ve Araștırma Hastanesi Cerrahi Kliniğinde opere edilen toplam 40 tiroid kanseri hastasinın verileri incelendi. Bu hastaların başvuru yakınmaları ve radyolojik görüntüleme bulguları, laboratuar sonuçları, yapılan cerrahi girișim verileri incelenmiștir.

Bulgular: 40 tiroid kanseri hastasının 25'i (\%62.5) kadın, $15^{\prime} i$ (\%27.5) erkek idi. Kadın hastaların 23'ü (\%92), erkek hastaların 13'ü (\%86.6) ötiroid idi. Hastalarımızın 29 (\%72.5)'u papiller kanser, 5 (\%12.5)'i folliküler kanser, 2 (\%5) si medüller kanser, 3 (\%7.5)'ü anaplastik kanser ve 1 (\%2.5)'i hurthle hücreli karsinom idi.

Sonuç: Tiroid kanseri cerrahisindeki değişikliklerin fazlalığl, hatta çoğu tiroid kanserinin takip edilmesi sonucu grupların oluşmasi, total tiroidektomi ve lobektomi arasinda evrilen cerrahi, bu tür çalıșmaların varlığının değerli olduğunu düșündürmektedir.

Anahtar Kelimeler: tiroid kanser, tiroidektomi

\section{ABSTRACT}

Objective: Thyroid cancers often appear as a solitary hypoactive nodule, but several difficulties in diagnosing malignancy of this nodule also make it difficult to choose the correct surgical intervention. We turned to this study to determine the choice of a surgical method for the diagnosis and treatment of thyroid cancer in patients who are operated with a thyroid cancer diagnosis.

Material and Methods: The data of a total of 40 thyroid cancer patients who were conducted at Haseki Training and Research Hospital Surgical Clinic were examined. The patients' admission complaints and radiological imaging findings, laboratory results and surgical intervention data were examined.

Results: Of the 40 thyroid cancer patients, 25 (62.5\%) were female and $15(27.5 \%)$ were male. Twenty-three (92\%) of female patients and 13 (86.6\%) were euthyroid. 29 (72.5\%) of our patients had papillary cancer, 5 (12.5\%) follicular cancer, $2(5 \%)$ medullary cancer, 3 (7.5\%) anaplastic cancer and 1 (2.5\%) hurthle cell carcinoma.

\section{İletişim}

Sorumlu Yazar: Ekrem FERLENGEZ

Adres: Sağlık Bilimleri Üniversitesi Haseki Eğitim Araştırma Hastanesi Genel Cerrahi Kliniği, 34096, İstanbul, Türkiye

Tel: +90 (532) 7133063

E-Posta: ekremferlengez1@yahoo.com

Makale Geliș: 06.11.2019

Makale Kabul: 22.11.2019

DOI: http://dx.doi.org/10.16948/zktipb.643830
Conclusion: The excessive changes in thyroid cancer surgery, even the formation of groups as a result of the follow-up of most thyroid cancers, the surgery that evolved between total thyroidectomy and lobectomy suggest that the existence of such studies is valuable.

Keywords: thyroid cancer, thyroidectomy

\section{GíRiş}

Endokrin kanserler grubunda yer alan tiroid maligniteleri özellikle ülkemizde beki de hasta özelliklerinin uluslararası rehberlere uymaması nedeni ile yönetimi kısmen diğer kanserlere göre daha karmaşı olarak nitelendirilmektedir.

Tiroid kanserleri iki ana epitelyal hücreden kaynaklanan kötü huylu tümörlerdir. Klinikte görülen kanser olgularının \%1'i kadarını meydana getirseler de endokrin tümörler içinde ikinci en s1k görülen tümörlerdir [1].

Tiroid kanserlerinin etiyolojisindeki en önemli faktörlerden bir tanesi endemik guatrdir. Tiroid kanserleri çok defa karşımıza soliter hipoaktif bir nodül olarak çıkmakta ancak bu nodülün malignite tanısı koyulmasındaki bir takım güçlükler uygulanan cerrahi girişim seçimini de zorlaştırmaktadır. Gerek kliniğimizde tiroid kanseri tanısı ile opere ettiğimiz, gerek başka merkezlerde opere edildikten sonra reoperasyon gereken bir kisim hastalarda, karsinom şüphesi ile radikal ameliyatların yapıldığ 1 hastaları gözlemlememiz üzerine; tiroid kanser tanısı ve tedavisinin uygulanması için gerekli cerrahi yöntem tercihini belirlemek amacıyla bu çalıșmaya yöneldik.

Tiroid kanserlerinde etyoloji kesin olarak bilinmemesine karşın birçok faktör rol oynamaktadır, özellikle iyi diferansiye karsinomlara endemik guatr bölgeleri ve çocukluk çağında radyasyona maruz kalmış kişilerde rastlanılmaktadır [2].

Eksternal 1şınlamaya bağlı olarak genellikle papiller karsinom oluşurken bu kanserler radyasyona maruz kaldıktan 5 y1l sonradan itibaren en çok 10-25 y1l sonra görülmektedir. Endemik guatr bölgelerinde folliküler tiroid karsinomu görülme insidansı yüksektir. Bu ilişki papiller kanserler arasında görülmemektedir [3].

Hipertiroidi nedeniyle radyoaktif iyot tedavisi gören hastalarda tiroid kanseri riskinin artmadığı, yakalanma insidansının normal popülasyon ile eşit olduğu gözlemlenmiştir. Ancak iyot yetersizliği, tiroidin hormon sentezindeki konjenital veya diğer nedenlerle oluşan defektlerinde, bir takım guatrojenlerin TSH artışına paralel olarak tiroid kanseri riskini arttırdığı görülmüşsür [4]. 
Bir takım patolojileri beraberinde taşıyan tiroid nodüllerinin çoğunun benign olmasına karşıllk soliter nodüllerde ortalama $\% 4.7$, multinodüllerde ise $\% 1$, dominant nodülde ise $\% 4.1$ maligniteye rastlanması tiroid nodüllerinde kanserleşme olduğunu göstermektedir [5].

Tiroid bezinin parafoliküler(C) hücrelerinden kaynaklanan medüller karsinom etyolojisinde yukarıda bahsedilen faktörlerin rolü olduğu kanıtlanmamıştır. Paratiroid adenom ve feokromasitoma ile birlikte olduğunda Men II Sendrom olarak adlandırılıp, \%50 oranında otozomal dominant geçiş söz konusudur. Tek başına görülen medüller tiroid kanserleri ise, sporadiktir [6].

Tiroid karsinomları içerisinde oldukça kötü prognoza sahip indiferansiye karsinomların gelișiminde belirleyici intrensek veya ekstrensek faktör gösterilememiştir. Bazı indiferansiye tümör alanları arasında papiller ve foliküller karsinom alanlarına rastlanılması tümörün diferansiasyonunun azalması sonucu ortaya çıktıklarını düşünmeye sevketmiştir. İndiferansiye tümörlerde ileri yaş önemli bir parametredir [7].

Tiroid kanserleri multinodüler guatrda \%0-11 , soliter tiroid nodülünde $\% 3-33$, ve soğuk nodülde \%2-20 oranında görülür [8]. İndiferansiye tiroid karsinomları organizmanın en kötü prognozlu tümörleri arasında yer alırlar. Hastalarımızın büyük bir bölümünün daha önce ameliyat olmuş hastalardan oluşma nedeni ile bu durumu gelecekte düzeltecek bir katkı oluşturma amacı ile verileri retrospektif olarak taramayı uygun bulduk.

\section{GEREÇ ve YÖNTEM}

Haseki Eğitim ve Araştırma Hastanesi Cerrahi Kliniğinde 1998-2002 yılları arasında toplam 40 hasta tiroid kanseri nedeni ile opere edildi. Bu hastaların başvuru yakınmaları ve radyolojik görüntüleme bulguları, laboratuar sonuçları, yapılan cerrahi girişim verileri incelenmiştir. Veriler retrospektif olarak toplandığından çalışma için etik kurul onayı alınmamıştır. Ancak tüm hastalardan hastaneye yatış esnasında verilerin anonim olarak bilimsel çalışmalarda kullanılabileciğine yönelik bireysel onam alınmıştır.

\section{BULGULAR}

Çalıșılan 40 tiroid kanseri hastasının 25'i (\%62.5) kadın, 15'i (\%27.5) erkek idi. Yaş dağıl1mında kadın hastalarda 20-30 yaş aralığında dört, $30-40$ yaş aralığında $12,40-50$ yaş aralığında yedi, $50-60$ ve $60-70$ yaş aralıklarında birer hasta mevcuttu. Kadınlarda 30-40 yaş aralığındaki yüksek oran erkeklerde gözlenmemiş ve daha dengeli bir dağ1$1 \mathrm{~m}$ tespit edilmiştir. Erkeklerde 30-40, 40-50 ve 60-70 yaş aralıklarında üçer; 50-60 yaş aralığında dört ve 70 yaş üzerinde iki hasta mevcut idi. Troid kanserli olgularımızda en sık semptom 35 hastada (\%87.5) görülen boyunda şişlik idi. Bunu 10 hastada (\%25) görülen nefes darlığı izlemekteydi.

Tiroid hormon ölçümleri tüm hastalara yapıldı. Kadın hastaların 23'ü (\%92), erkek hastaların 13 'ü (\%86.6) ötiroid idi. Kadın hastalarda 2 (\%8), erkek hastalarda da 1 (\%6.6) kiși hipertiroidi idi. 1 (\%6.6) erkek hastada hipotiroidi saptandı. Hipertiroidili hastalardan ikisi endokrin kliniğinde hipertiroidi nedeniyle tedavi görmüş, ardından İ̇AB ile malignite saptanıp, kliniğimize sevk edilmişti. Bir hastada ise hipertiroidiye anti-tiroid ilaçlar ile yanıt alınamamıştı.

Hastaların 18'i daha önce operasyona alınıp, postoperatif malinite tanisı piyesin patolojik incelemesi ile koyulduğundan, bu hastaların USG'sinde $14(\% 77.7)$ hastada rezidü tiroid dokusu, $4(\% 22.2)$ hastada servikal lenf nodu saptanmıştır.

Bütün hastalarımızın tiroid sintigrafısi ile değerlendirmeye tabi tutulmuştur. İlk kez opere edilecek 22 tiroid kanserli hastanın 16 (\%72.7)'sinda soliter nodül saptandı. Bu nodüllerin 14'ü (\%63.6) soğuk, 2'si (\%9) sicak nodüldü. 4 (\%18.1) hastada multinodüler guatr, $2(\% 9)$ hastada ise nonfonksiyone tiroid bezi saptandi.

Reoperasyona alınan 18 hasta rezidü tiroid dokusu açısından değerlendirmeye alındı. Bu hastaların 14 (\%77.7)'ünde rezidü tiroid dokusu saptanırken 4 (\%22.2)'ünde iyot uptake gözlenmemiştir.

Daha önce operasyona alınıp ardından malignite tanısı ile reoperasyona alınan 18 hastaya İIAB yapılmamıştır. Diğer 22 hastanın 14 (\%63.6)'ünde malign, $5(\% 22.7)$ hastada ise benign bulgular saptanmıştır. Geriye kalan $2(\% 9)$ hastada şüpheli hücreler görülmüş, $1(\% 4.5)$ hastada ise yetersiz materyal olduğu için değerlendirme yapılamamıştır. $\mathrm{Bu}$ hastaya USG eşliği altında yapılan İİAB sonucu malignite saptanmıştır.

Hastalarımızın 29 (\%72.5)'u papiller kanser, 5 (\%12.5)'i folliküler kanser, 2 (\%5)'si medüller kanser, $3(\% 7.5)$ 'ü anaplastik kanser ve $1(\% 2.5)$ 'i hurthle hücreli karsinom idi.

Toplam 17 hastada papiller Ca tanisı koyulmuştu. Bunlardan 13'üne total tiroidektomi ve tümör tarafındaki lenfatik santral boyun diseksiyonu uygulandi. Dört hastada palpabl selvikal lenf nodu olduğu için, tümör tarafina modifiye radikal boyun diseksiyonu eklendi. Toplam iki hastada folliküller neoplazm mevcuttu. Tümör tarafi total lobektomi ve istmektomi uygulandı. Medüller Ca'lı iki hastaya total tiroidektomi ve tümör tarafına modifiye radikal boyun diseksiyonu yapıldı. Üç hastada anaplastik tümör saptand1. İki hastaya trakeostomi, bir hastaya da debulking cerrahi işlem uygulandi.

Reoperasyona alınan grupta 12 papiller $\mathrm{Ca}^{\prime} \mathrm{l}_{1}$ hasta mevcuttu. Bunlardan 4'üne totale yakın tiroidektomi uygulandi. Diğer hastalardan beşine total tiroidektomi uygulandı. Bu hastaların juguler lenf düğümlerinden yapılan örneklemenin negatif olmasindan dolayı lenfatik diseksiyon uygulanmadi. Diğer üç hastaya ise total tiroidektomi yanında lenfatik örneklemenin pozitif olması nedeniyle ve modifiye radikal boyun diseksiyonu uyguland.

Folliküler Ca tanısı ile reoperasyona alman beş hastanın dördüne ,total tiroidektomi uyguland, bir hastaya ise lenf nodu metaztazı sebebiyle total tiroidektomi yanında modifiye radikal boyun diseksiyonu yapıld1. Hurthle hücreli karsinom sebebiyle bir hastaya tamamlayics total tiroidektomi ve lenf nodu pozitif olduğu için modifiye radikal boyun diseksiyonu uyguland1. 
Komplikasyon açısından kanser tanısı konularak operasyona alınan hastalar ile, postoperatif kanser tanısı konularak reoperasyona alınan gruplar karşılaştırıldı. İlk kez ameliyata alınan grupta $2(\% 9)$ hastada geçici hipoparatiroidi, reoperasyona alınan grupta ise, $4(\% 22)$ hastada geçici hipoparatiroidi, $1(\% 5.5)$ hastada kalıc hipoparatiroidi saptand1. Reoperasyona alınan hastalardan birinde preoperatif tümör tarafındaki vokal kord hareketsiz idi. Uç hastada ise, postop vokal kord paralizisi saptand1. Bunlardan $2(\% 11)$ hastada kalıcı rekürrens hasarı görüldü. Kanser tanısı koyularak ameliyata alınan 22 hastanın ikisinde ses k1sıklığı mevcuttu. Postoperatif 2. Gruptaki $2(\% 11)$ hastada ve 1. Gruptaki $1(\% 4.5)$ hastada trakeomalazi saptand1. Bu komplikasyonlar dışında belirgin bir komplikasyon saptanmadi.

\section{TARTISMMA}

Tiroid karsinomlarının çoğu klinikte küçük nodulun hasta tarafindan farkedilmesi oldukça güçtür. Ayrıca bu nodüllerin çoğu asemptomatiktir. Siklıkla doktor tarafından tespit edilebilir. Hastaların az bir kısmında yutma güçlüğü, nefes darlığı ve ses k1sıklığ 1 mevcuttur. Bizim tiroid karsinom vakalarımızda başvuru şikayeti en sık \%87.5 oranıyla boyunda şişlik olmuştur. Bunların çoğunda muayenede palpabl nodüller mevcuttu. Ancak, bize başvuran iki hastamızda yutma zorluğu ve ses k1sıklığ1 semptomu mevcuttu. Daha sonradan bu iki hastanın anaplastik karsinom olduğunu saptadık. Her ne kadar semptomlar lezyonun benign veya malign olduğunu ayırt etme konusunda yardımcı olmasa da ilerlemiş bir tiroid karsinomunda veya indiferansiye tiroid karsinomunda özellikle nefes darlı̆̆1 ve ses k1sıklığ1 şikayetinin önemli bir semptom olduğunu düşünmekteyiz.

Tiroid nodüllerinin çoğunun kadınlarda görülmesine karşılık, karsinom oranı erkeklerde kadınlara nazaran daha fazladır. Ancak bizim olgularımızın büyük çoğunluğunu kadın hastalar teşkil etmekte idi (\%62.5).

Tiroid kanserlerinin tanısı için sintigrafi. preoperatif sık kullanılan tan, yöntemlerinden birisidir. Bizim de sintigrafi yaptığımız hastaların 18'i daha önce opere edilmiști. Bu hastaların 14 (\%77.7)'ünde rezidü tiroid dokusu saptand1. 4 (\%22.2)'ünde iyot uptake saptanmadi. Diğer 22 hastanın 14 (\%87.5)'ünde soliter ve soğuk nodul, 2 (\%12.5)'sinde sıcak nodüle rastlanıldı. Tiroid kanserlerinde görülen solid nodüllerin sintigrafik olarak yüksek oranlı soğuk olması vakalarımızda da belirgin bir şekilde ortaya çıktı. Bu bulgular literatür ile uyumlu idi [9]. Bununla beraber sintigrafide nonfonksiyonel veya hipoaktif görülen lezyonun selim adenom, kist, hematom, apse, lenfoma, hidatik kist ve lokalize tiroidit gibi hastalıklarda da olabileceği akılda tutulmalidir.

Tiroid sintigrafisinde multinodüler guatr veya diffüz guatr tanısı almış hastalarda tiroid kanseri görülme olasılığ 1 mevcuttur. Yaptığımız çalışmada 4 (\%18.1) hastada sintigrafik olarak multinodüler guatr tanis1 mevcut olup, bu hastalarda tiroid karsinomu saptanmıştı. Bu nedenle sintigrafi tiroid kanseri tanısında güvenilir olmamakla birlikte soliter ve soğuk büyük nodül varlığında kanser olasılığı akla gelmelidir.

Bizim de sintigrafik olarak hipoaktif nodül saptadığımız 14 (\%63.6) hastaya yapılan USG'de çoğunun soliter ve hipoekoik karakterde olduğu gözlendi. Ultrasonografik olarak açıkça çevre dokulara invazyon varlığı, boyun damar sinir paketine yayılım, trakeaya infiltrasyon, nodül içinde kalsifikasyon veya nekroz saptanmas1, tiroid karsinomu lehine değerlendirilmiştir.

USG'nin diğer bir faydası nodüllerin büyüyüp büyümediğinin belirlenmesidir. İİAB'de bening sitolojik özellik gösteren ve supresyon tedavisi altındaki hastaların izlenmesidir. Ayrıca palpe edilmeyen ya da radyoaktif iyot tutmayan lenf dügüüü metaztazlarının belirlenmesinde de USG oldukça yararlı bir tekniktir. Bizim de hurthle hücreli kanser tanısı ile öpere ettiğimiz bir hastanın takibinde ultrasonografik olarak 10 ay sonra boyun lenf metastaz1 saptanılmış, hastaya reoperasyon yapılmıştır.

Hastalarımızın tümüne İİA yapılmıştır. Bunlardan beş hastada patoloji, sonucu benign olarak tespit edilmiştir. Ancak, üç hasta klinik olarak malign bulgular gösterdiğinden dolayı, opere edilmiş, iki hasta da peroperatif olarak maligniteyi düşündürecek aşırı sertlik ve çevre dokulara invazyon olması nedeniyle frozen-section yapılmış, sonucun malign gelmesi üzerine tiroid kanser cerrahisi uygulanmıştır.

Günümüzde ameliyat öncesi malign-benign ayırımı en iyi şekilde İ́AB yapılabilmektedir. Bu yöntemle ayırım yapılabilen lezyonlarda cerrahi tedavi gerekip gerekmediği, cerrahi gereken olgularda hangi tip ameliyat yapılabileceği planlanabilmektedir. Bizim hastalarımızın 22'sine İIAB yapılmış, bunların 14 (\%63.6)'ünün malign gelmesi üzerine cerrahi teknik buna göre planlanmıștır. Bizim İIAB yaptığımız 22 hastanın 2 (\%9)'sinde hematom oluşmuş, ancak bunların hiçbirisine tedavi gerekmemiştir. Klinik olarak ileri derecede çevre dokulara yayılım şüphesine neden olan ve İİAB ile malign olduğu saptanan dört hastaya servikal tomografi endikasyonu koyuldu, bunlardan üç hastada servikal tomografide ameliyat prosedürünü etkileyecek anlamlı bulgular saptand1.

Bilgisayarlı tomografi özellikle metastaz ve çevre doku invazyonunu göstermede en etkili yöntemdir. Boyun-damar ve sinirlerine invazyon cerrahi girişim için ameliyat öncesi mutlaka bilinmesinin gereken bir durumdur. Hastalarımızdan üçünde juguler ven ve karotis arter tutulumu saptanmış, ikisi anrezektabl kabul edilmiş, IIIAB sonucu anaplastik karsinom gelmesi üzerine, solunum sıkıntısı nedeniyle trakeostomi açılmıştır.

Ameliyat sırasında nodülün makroskobik görünümüne bakarak malign veya benign olduğunu söylemek çok defa mümkün değildir. Papiller, foliküler ve medüller tiroid karsinomlarının çoğu klinikte soliter non fonksiyone nodul şeklinde ortaya çıkarlar.

Bazı araştırıcılar rutin olarak frozen sectionu önerirken, son yıllarda alınan neticelere göre, iyi bir teknik ile yapılan İIAB'ye üstünlüğü gösterilememiştir. Frozen sectionda da foliküler neoplazm 
ile karsinom ayırımı yapılamamaktadır. Karsinom tanıs1 için önemli histolojik bulgu invazyondur. Kapsüle komşu tiroid dokusuna veya damarlara ait invazyon saptanmazsa kanser tanısı koyulamaz. Bir nodülün yalnız merkezinin muayenesi yeterli olmayabilir. Nodülün periferik kısmının da dikkatli bir şekilde incelenmesi ve çok sayıda kesit yapılması gerekir. Bu da ancak parafin kesitlerle mümkün olmaktadır. Sonuç olarak, çok sayıda tanı yönteminin bulunmasına rağmen, soliter non-fonksiyone tiroid nodüllerinde nodülün benign veya malign olduğu konusunda anamnez, fizik muayene ve laboratuvar tekniklere dayanarak kesin bir yargıya varılmasının son derece güç olduğunu söyleyebiliriz. Ancak bu konuda İİA'nin malignite tanisı konulmasinda en faydalı yöntem olduğu düşüncesindeyiz.

İlk ameliyatta tiroid kanseri olduğu bilinmeyen hastaların patoloji sonucunun karsinom olmasi durumunda diferansiye tiroid karsinomlarının prognozunun iyi olması gözüne alınarak tamamlayıc1 tiroidektomi konusunda iyi bir değerlendirme yapılması gerekmektedir. Kliniğimizde de reoperasyon kararını alırken hastanın yaşı (70 yaş altı olması), yaşam beklentisinin uzun olması, hastanın genel durumu göz önünde tutularak, hastada primer tümörün diferansiye olması, tümör çapının 1,5 cm'den büyük olması ve multisentrik tümör bulunması hallerinde tamamlayıcı tiroidektomi uygulanmıștır.

Bizim serimizde toplam 29 papiller karsinomlu hastanın 17'sinde preoperatif tanı koyularak cerrahi uygulanmış, diğer 12 hastaya ise, reoperasyon kararı alınarak cerrahi uygulanmıştır. Tümörün olduğunu bilerek operasyona aldığımız 17 hastanın tamamina total tiroidektomi ve santral boyun diseksiyonu uygulandi.

Reoperasyon uyguladığımız 12 hastanın dördüne tümör tarafında yapışıklıklar ve skar dokusu nedeniyle totale yakın tiroidektomi uyguland, diğerlerinde ise total tiroidektomi uyguland.

17 hastanın dördünde palpabl servikal lenf ganglionunun olması nedeniyle tiroidektomiye ilave olarak tümör tarafina modifiye radikal boyun diseksiyonu uygulandı. Reopere ettiğimiz 12 papiller tiroid kanser hastasında lenfatik metaztaz olasılığ nedeniyle jüguler örnekleme yapıld1, neticesinde üçünün pozitif olması üzerine, santral lenfatik diseksiyonuna modifiye radikal boyun diseksiyonu ilave edildi.

İİAB folliküler neoplazm olarak gelen iki hastamıza aynı tarafa total lobektomi, istmektomi yapıldı. Reoperasyon grubunda iki hastanın patoloji sonucu folliküler karsinom olması nedeniyle bunlara tamamlayıcı total tiroidektomi uygulandi.

Bir hastada da ilk ameliyatta alınan palpabl lenf düğümü metaztaz gelmesi üzerine modifiye radikal boyun diseksiyonu uygulanmıştır, iki medüller karsinomlu hastaya total tiroidektomi ve tümör tarafina modifiye radikal boyun diseksiyonu uygulandi.

Hurtle hücreli karsinom nedeniyle bir vakam1za tamamlayıc tiroidektomi yapıldı. Hastanın lenf ganglionları örneklemesinin müspet olması üzerine total troidektomi yanında modifiye boyun diseksiyonu eklendi. Ancak aynı hastamız operasyondan 10 ay sonra yapılan servikal ultrasonografisinde lenf metastazı ile uyumlu bulgular saptanması üzerine biyopsi yapılarak metastaz teyid edildi. Her ne kadar iyi diferansiye tümörler içinde yer alsa da hurthle hücreli tioid kanserinde artmış nüks gelişme olasılığını bu vakamız doğrulamaktadır. Üç hastamızda IIIAB sonucu anaplastik tümör saptand1, bu hastalardan ikisinde trakea invazyonu ve genel durum bozukluğu, aynı iki hastadan birisinde uzak metastaz (vertebra) olması nedeniyle trakeostomi açıldı, diğer bir hastaya ise debulking uygulandı. Her üç hastamız da ortalama 4-8 hafta içinde kaybedildi.

Komplikasyonların başında kalıcı hipoparatiroidi ve kalıcı nervus laryngeus rekürrens paralizisi gelmektedir. Rekürrens sinir paralizisi \%2-5 oranında bildirilmekte ise de bu konuda uzmanlaşmış merkezlerde bu oranın ihmal edilebilecek düzeyde olduğu bildirilmektedir. Bizim serimizde reopere ettiğimiz hastalardan 4 (\%22.2)'ünde geçici hipoparatiroidi saptandı. Bunlardan üç hasta yaklaşık 6 aylık medikal tedavi ile iyileşti. Ancak, bir hastada ameliyat sonrası 11 ay geçmesine ve medikal tedavi devam etmesine rağmen düzelme saptanmamıştır. Bu hastada kalıcı hipoparatiroidi geliştiğini düşünmekteyiz. Bunu kalıcı hipoparatiroidi kabul ettiğimizde, bu komplikasyon oranımız 1 (\%5.5) olmuştur. Reoperasyona gerek görmediğimiz hastalarımızdan $2(\% 9)$ 'sinde yaklaşık 6 hafta süren geçici hipokalsemi bulguları nedeniyle tedavi edilmiş, tedavi sonrası hipokalseminin klinik ve laboratuvar bulguları normal seviyeye gelmiştir. Literatürde tamamlayıc1 tiroidektomi sonrası geçici hipoparatiroidizm insidansi \%3-15 arasındadır. Kalıc hipotiroidizm insidansı ise değişik serilerde $\% 0$-3 olarak bildirilmiştir [10].

Reoperasyon endikasyonu koyduğumuz tüm hastaların preoperatif dönemde indirek laringoskopi ile vokal kord hareketleri değerlendirildi. Bilateral subtotal tiroidektomili bir hastamızda tümör bulunan lob tarafindaki vokal kordun hareketsiz olduğunu saptadık (\%5.5). İki hastanın ses kısıklığı şikayeti olmasına rağmen, indirek laringoskopide patolojik özellik saptanmadı. Reoperasyon sonucunda vokal kord paralizili hastanın kontrol laringoskopisinde preop bulguların postop dönemde de aynı olduğu görüldü. Bu hasta haricindeki diğer 14 hastadan birinde hasta ameliyat masasında extube edildikten sonra solunum sikintıs1, stridor ve siyanozun gelişmesi üzerine, gerekli medikal yaklaşıma cevap alınamad, indirek laringoskopide her iki vokal kordun orta hatta fikse vaziyette olması üzerine hastaya ameliyat masasında trakeostomi yapıldı. $\mathrm{Bu}$ hasta aşırı fibrozis nedeniyle nervus laryngeus rekürrensi ortaya koyamadığımız hasta grubunda idi. İki hastada da solunum sikintısı ve stridorun postoperatif bir saate kadar devam etmesi yapilan indirek laringoskopide her iki vokal kordun arasında minimal açıklığın saptanması üzerine, bu iki hastaya da trakeostomi açıldı. Hastaların takibinde operasyon sonrası bir hastada 4. ayda vokal kord hareketlerinin başlaması ve trakeostomisiz tolere etmesi üzerine trakeostomisi çekildi. Diğer iki hastada klinik ve laringoskopik bulgular her iki vokal kort paralizisini düşündürdüğünden dolayı hastalar trakeostomili olarak takip edildiler. Tamamlayıc1 tiroidektomi 
yaptığımız 18 hastanın dördü yaklaşık üç hafta sonra reoperasyona aldığımız hastalardı.

Dört hastada aşırı fibrozis nedeniyle rekürren sinirler ortaya koyulamad1. Preop dönemde tiroid kanser tanısı koyarak opere ettiğimiz ve reoperasyon düşünülmeyen 22 hastadan 2 (\%9)'sinde ses k1sıklığı mevcuttu. Laringoskopide bir hastada tek taraflı paralizi saptandı, diğer hastanın laringoskopik muayenesinde patoloji saptanmadi. Postoperatif üçüncü haftada bu şikayetlerin gerilediğini saptadik. A.Eroğlu (11) ve arkadaşlarının tamamlayıcı tiroidektomi yaptıkları hastalarda kalıcı vokal kort paralizisi insidansını \%5.4 olarak saptamalarına rağmen, bizim reopere ettiğimiz hastalardaki oranımız 2 (\%11.1) olarak saptanmıştır. Bu oranın yüksekliği hasta sayımızın azlığ 1 nedeniyle anlamsız olarak değerlendirilebilir. Tamamlayıcı tiroidektomide nervus laryngeus rekürrens hasarı ve hipoparatiroidi riskini arttıran adezyonlara ve skar dokusuna bağlı olarak anatomik bütünlügüün bozulmasıdır. $\mathrm{Bu}$ nedenle A.Eroğlu ve arkadaşlarının önerdiği gibi tamamlayıcı tiroidektominin skar dokusu gelişmeden ilk ameliyatı izleyen 5. gün içinde gerçekleştirilmesi ya da enflamasyon ve ödemin gerilemesi beklenerek 3-4 aylık bir dönem sonrası yapılması gerektiği düşüncesine katılıyoruz [11]. Şöyle ki, her ne kadar başka faktörler rol oynasa da laryngeal siniri prepare edemememizde erken dönemde reoperasyon yapmamıza bağlı varolan fibrozis ve yapışıklıklar da rol oynamış olabilir. Patolojik tanının ilk ameliyatın şüpheli olduğu hastalarda erken koyulması reoperasyon zamanlamasında önemli rol oynamaktadır. Böyle durumlarda cerrah ve patoloğun iş birliği içinde olması komplikasyon oranını düşürebilir kanaatindeyiz.

Tamamlayıcı tiroidektomi yapılan bir hastamizda internal juguler ven iatrojenik olarak yaraland1, primer olarak onarıld1.

Tiroid kanseri cerrahi, kemoterapi ve radyoterapi seçenekleri ile tedavi edilebilen bir tümördür. Gereksiz tiroidektomi ve boyun eksplorasyonlarından kaçınmak için ve tedavinin planlanması açısından preoperatif tanı yöntemlerinin kanser tanısını koymadaki etkinliğini arttırılması gerekir. Preoperatif tan1 yöntemlerinden IİAB'nin mevcut tan1 yöntemleri içinde uygun yapılıp, değerlendirildiğinde kanser tanısı koymada çok önemli bir yöntem olduğunu gördük. Ameliyat düşünülen soliter hipoaktif tiroid nodüllerinin hepsine İIAB yap1larak cerrahi işlemin uygulanması taraftarıyız. Böylelikle hastaları hem reoperasyon risk ve komplikasyonlarından koruyabileceğimiz ve ayrıca kanser şüphesi ile uygulanacak gereksiz radikal ameliyat ve buna bağlı morbidite ve komplikasyon artışını düşürebileceğimiz kanaatindeyiz.

Tiroid kanser ve tamamlayıcı tiroidektomi cerrahisinin, yüksek komplikasyon ihtimali nedeniyle deneyimli kişiler tarafindan ve deneyimli merkezlerde yapılması gereklidir. Reoperasyon komplikasyon oranlarını azaltmada operasyon zamanlaması önem arzetmektedir. Deneyimli merkez olmamıza ve riskli vakalarda kimi zaman total yerine totale yakın tiroidektomi uygulamamıza rağmen komplikasyon oranının yüksekliği 40 hastalık serimizin 18 tanesinin önceden opere edilmiş hastalar tarafın- dan oluşturulması idi. Elde ettiğimiz verilere göre komplikasyon açısından ilk ameliyat tek ameliyat olmalı prensibinin oturtulması gerekmektedir.

Ulaştığımız sonuç aslında ülkemizde yerel rehber algoritma eksikliğinin vurgulanması gerekliliğidir. Artık günümüzde hiçbir merkezde bu tür hastalardan oluşmuş bir seri toplanamayacağı gerçeği, bulgularımızı paylaşma ihtiyacını doğurmuştur. Diğer kanserlerin aksine tiroid cerrahisindeki değişikliklerin fazlalığ 1 , hatta çoğu tiroid kanserinin takip edilmesi sonucu grupların oluşması, total tiroidektomi ile lobektomi arasında evrilen cerrahi, bu tür retrospektif datayı değerli kılmaktadır.

\section{KAYNAKLAR}

1. Cabanillas ME, McFadden DG, Durante C. Thyroid cancer. Lancet 2016;3;388(10061):2783-2795.

2. Takano T. Natural history of thyroid cancer. Endocr $J$ 2017;31;64(3):237-244

3. Albi E, Cataldi $S$, Lazzarini A, Codini M, Beccari T, Ambesi-Impiombato FS, et al. Radiation and Thyroid Cancer. Int J Mol Sci 2017;26;18(5).

4. Schmidt A, Iglesias L, Klain M, Pitoia F, Schlumberger MJ Radioactive iodine-refractory differentiated thyroid cancer: an uncommon but challenging situation. Arch Endocrinol Metab 2017;61(1):8189.

5. Nabhan $F$, Ringel MD. Thyroid nodules and cancer management guidelines: comparisons and controversies. Endocr Relat Cancer 2017;24(2):R13-R26.

6. Accardo G, Conzo G, Esposito D, Gambardella C, Mazzella M, Castaldo $F$, et al. Genetics of medullary thyroid cancer: An overview. Int J Surg 2017;41 Suppl 1:S2-S6.

7. Schmidbauer B, Menhart K, Hellwig D, Grosse J. Differentiated Thyroid Cancer-Treatment: State of the Art. Int J Mol Sci 2017;17:18(6).

8. Roman BR, Morris LG, Davies L. The thyroid cancer epidemic, perspective. Curr Opin Endocrinol Diabetes Obes 2017;24(5):332336.

9. Chowdhury S, Mukherjee S, Mukhopadhyay S, Mazumder R. The thyroid nodule evaluation and management. J Indian Med Assoc 2006; 104(10):568-70,572-3.

10. Christou N, Mathonnet M. Complications after total thyroidectomy. J Visc Surg 2013;150(4):249-56.

11. Eroğlu A, Berberoğlu U, Buruk F, Yildirim E. Completion thyroidectomy for differentiated thyroid carcinoma. J Surg Oncol 1995;59(4):261-7. 